\title{
Thresholds of copper toxicity to lettuce in field-collected agricultural soils exposed to copper mining activities in Chile
}

\author{
J. Verdejo ${ }^{1}$, R. Ginocchio ${ }^{2,3}$, S. Sauvé ${ }^{4}$, P. Mondaca ${ }^{1}$, A. Neaman ${ }^{1 *}$ \\ ${ }^{1}$ Escuela de Agronomía, Pontificia Universidad Católica de Valparaíso, Quillota, Chile. ${ }^{2}$ Departamento \\ de Ecosistemas y Medio Ambiente (DEMA), Facultad de Agronomía e Ingeniería Forestal, Pontificia \\ Universidad Católica de Chile, Santiago, Chile. ${ }^{3}$ Center of Applied Ecology and Sustainability (CAPES), \\ Pontificia Universidad Católica de Chile, Santiago,Chile. ${ }^{4}$ Department of Chemistry, Université \\ de Montréal, H3C 3J7, Montréal, QC, Canada.*Corresponding author: alexander.neaman@ucv.cl
}

\begin{abstract}
Several previous studies highlighted the importance of using field-collected soils instead of artificially spiked contaminated soils for phytotoxicity tests. However, the use of field-collected soils presents several difficulties for interpretation of results, due to presence of various contaminants in the soil and unavoidable differences in the physicochemical properties of the tested soils. The objective of this study was to estimate thresholds of copper phytotoxicity in topsoils of 27 agricultural areas historically contaminated by mining activities in Chile. We performed standard emergence and early growth (21 days) tests (OECD 208 and ISO 11269-2) with lettuce. The response of lettuce was best explained by $\mathrm{Cu}$ toxicity and P deficiency. Growth of lettuce was related to soil total $\mathrm{Cu}$ concentration and Olsen-P and was not affected by soluble $\mathrm{Cu}$ (extractable by $0.1 \mathrm{M} \mathrm{KNO}_{3}$ ) or $\mathrm{Cu}^{2+}$ free ion activity of the soil solution. Thus, lettuce has a limited applicability for metal toxicity assessment in metalcontaminated soils, due to sensitivity of its response to P deficiency. However, it was possible to determine toxic thresholds for shoot concentrations of $\mathrm{Cu}$ in lettuce for responses of shoot and root length, suggesting that shoot concentrations of $\mathrm{Cu}$ in lettuce can be useful as indicators of $\mathrm{Cu}$ toxicity even in soils with a wide range of nutrient concentrations.
\end{abstract}

Keywords: Bioavailability, copper, $\mathrm{EC}_{50}$, lettuce, toxicity

\section{Introduction}

Environmental problems associated with such as $\mathrm{Cu}, \mathrm{Zn}, \mathrm{Pb}$, and $\mathrm{Cd}$, and metalloids (As) (De copper mining in Central Chile are widely Gregori et al., 2003; Ginocchio, 2000; González et al., known, particularly in relation to the historical contamination of agricultural soils with metals, 1984). It is well known that soil contamination with metals diminishes its quality and presents a risk for 
soil functioning (Adriano, 2001). Lettuce (Lactuca sativa $\mathrm{L}$.) is recommended as an indicator organism in bioassays for assessment of soil quality (ISO 11269-2, 2005; OECD 208, 2006).

Several previous studies highlighted the importance of using field-collected soils - and not artificiallycontaminated soils - for phytotoxicity tests for assessment of soil quality of metal-contaminated soils (Hamels et al., 2014; McBride et al., 2009; Smolders et al., 2009). Likewise, the latest version of the protocol of soil quality tests with plants (ISO 11269-2, 2012) also considers field-collected soils, instead of artificially-contaminated soils. However, there might be several difficulties in interpreting the results of bioassays in field-collected soils. First, in areas near copper mining activities in Chile, soils have high concentrations of several metals $(\mathrm{Cu}, \mathrm{Pb}$, $\mathrm{Zn}, \mathrm{Cd}$ and As, among others) (De Gregori et al., 2003; Ginocchio et al., 2004). In this case, it might be difficult to distinguish between the effects of different metals on plant responses. Second, the intrinsic physicochemical characteristics of the soil, such as $\mathrm{pH}$, texture and organic matter content, among others, also affect the degree of toxicity of the metals present in the soil (Adriano, 2001; McBride, 1994; Rooney et al., 2006). Finally, differences in nutrient availability in the soil and its physical properties may also affect the plant responses, in addition to metal toxicity.

Recognizing the above-mentioned difficulties in interpreting the results of plant tests in field-collected soils, raises the question if a detailed characterization of soil properties and metal concentrations in plant tissues allows differentiating the metal-related effects and other confounding effects in field-collected agricultural soils exposed to copper mining activities? If the responses were affirmative, it would be possible to estimate thresholds of metal toxicity in soil. Thus, in the present study we aimed to: (1) differentiate confounding factors from metal-toxicity factors affecting lettuce growth in field-collected agricultural soils exposed to copper mining activities, (2) estimate thresholds of metal toxicity to plants in these soils.

\section{Materials and Methods}

A detailed description of methodology can be found in our previous study (Verdejo et al., 2015) and in the Online Supplementary Material (www.webcitation. org/6bEciJFes). Topsoils of 27 agricultural areas historically contaminated by mining activities in Chile were used in this study (See Online Suplementary Table 1). The general physicochemical characteristics of the soils, total and soluble concentrations of $\mathrm{Cu}, \mathrm{Pb}, \mathrm{Zn}$ and $\mathrm{As}$, and the activity of free $\mathrm{Cu}^{+2}$ were determined (See Online Suplementary Table 2 and 3). Fertility analysis was conducted on soils by determining the available nitrogen, phosphorus and potassium.

The biotesting was based on ISO 11269-2 (2005) and OECD 208 (2006). Lettuce (Lactuca sativa L.), variety Winter Gallega, was used for the assessment of metal phytotoxicity. A growth chamber was used for the test. Biotesting was carried out with four replicates. The containers were placed in the growth chamber using a fully randomized design. Ten seeds were sown per container, which were thinned out on day seven to leave only five plants in each container. The total length of the test was 21 days, including the germination period. Upon completion of the biotesting, a record was made of the length of each individual plant (shoot and longest root) along with the dry biomass of shoots and roots. Metal concentrations $(\mathrm{Cu}, \mathrm{Pb}, \mathrm{Zn}$ and $\mathrm{As})$ and nutrient concentrations (See Online Suplementary Table 4) were measured at the end of the testing.

Simple and multiple regressions were carried out between the biological responses and the 
physicochemical characteristics of the soils. Statistical analyses were carried out using Minitab 16. Effective concentrations $\left(\mathrm{EC}_{\mathrm{x}}\right)$ were determined by the Toxicity Relationship Analysis Program (TRAP) version 1.22 (US EPA, 2013).

\section{Results and Discussion}

Total soil concentrations of $\mathrm{Cu}, \mathrm{Zn}, \mathrm{Pb}$, and $\mathrm{As}$ were weak indicators of the lettuce response; the same was true for soluble concentrations of the elements and free $\mathrm{Cu}^{2+}$ activity (See Online Suplementary Table 5). However, shoot metal concentrations were good predictors of the lettuce response (See Online Suplementary Table 6). Also, the lettuce responses were determined by soil available P (Olsen-P) and $\mathrm{P}$ shoot concentration (See Online Suplementary Table 7). Despite the fact that Olsen-P was high ( $>15$ $\mathrm{mg} \mathrm{kg}^{-1}$ ) in most of the studied soils (See Online Suplementary Table 8) shoot P concentrations were below the normal value for lettuce (See Online Suplementary Table 9). Shoot $\mathrm{P}$ concentrations were correlated with Olsen- $\mathrm{P}\left(\mathrm{R}^{2}=0.21, p<0.05\right)$.

Stepwise regression analysis revealed that lettuce responses were best explained by $\mathrm{Cu}$ and $\mathrm{P}$, with both variables being significant $(p<0.05)$ in the following equations:

Shoot length $=8.5-0.003$ total soil $\mathrm{Cu}+0.042$ available soil $\mathrm{P}($ Olsen-P)

$\left(\mathrm{R}^{2}=0.58 ; p<0.001\right)$

Shoot length $=8.5-0.263$ shoot $\mathrm{Cu}+17$ shoot $\mathrm{P}$

$\left(\mathrm{R}^{2}=0.69 ; p<0.001\right)$,

where shoot length is in $\mathrm{cm}$, while total soil $\mathrm{Cu}$, available soil $\mathrm{P}$, shoot $\mathrm{Cu}$, and shoot $\mathrm{P}$ are in $\mathrm{mg} \mathrm{kg}^{-1}$.
Importantly, there was no correlation between total soil $\mathrm{Cu}$ and available soil $\mathrm{P}(\mathrm{Olsen}-\mathrm{P})$, nor between shoot $\mathrm{Cu}$ and $\mathrm{P}$ concentration $(p>0.05)$. At mean Olsen-P (48 $\left.\mathrm{mg} \mathrm{kg}^{-1}\right)$, the equation (1) predicts that the shoot length would be reduced by $10 \%, 25 \%$ and $50 \%$ at soil total $\mathrm{Cu}$ concentrations of $445 \mathrm{mg} \mathrm{kg}^{-1}$, $955 \mathrm{mg} \mathrm{kg}^{-1}$ and $1805 \mathrm{mg} \mathrm{kg}^{-1}$, respectively. The 95\% confidence intervals of these $\mathrm{EC}_{\mathrm{x}}$ thresholds were also estimated using the $95 \%$ confidence intervals of the mean values of Olsen-P (See Online Suplementary Table 10).

It has been reported that $\mathrm{Cu}$ toxicity reduced $\mathrm{P}$ uptake by crops (Reuther, 1957; Rhoads et al., 1992). However, a factorial regression revealed that the interaction between $\mathrm{Cu}$ and $\mathrm{P}$ was not statistically significant $(p>0.05)$, thus suggesting that these two factors are independent of each other in the present study.

These findings differ from results of our previous study with the same set of soils (Verdejo et al., 2015), in which we reported that the effects of soil nutrient availability on the ryegrass responses were not significant. Thus, lettuce has a limited applicability for metal toxicity assessment in field-collected metalcontaminated soils, due to sensitivity of its response to $P$ deficiency often observed in non-agricultural areas. Despite the above-mentioned confounding effects, it was possible to determine effective $\mathrm{Cu}$ shoot concentration $\left(\mathrm{EC}_{\mathrm{X}}\right)$ for lettuce responses. We derived the $\mathrm{EC}_{10}, \mathrm{EC}_{25}$ and $\mathrm{EC}_{50}$ values for $\mathrm{Cu}$ shoot concentrations in lettuce, using shoot and root length as response variables (Table 1 and Online Supplementary Figure 1). The $\mathrm{EC}_{\mathrm{X}}$ values for the shoot length response were similar to the $\mathrm{EC}_{\mathrm{X}}$ values for the root length response, suggesting that both responses can be useful as indicators of $\mathrm{Cu}$ toxicity in field contaminated soils. 
Table 1. Effective concentration $\left(\mathrm{EC}_{10}, \mathrm{EC}_{25}\right.$ and $\left.\mathrm{EC}_{50}\right)$ of shoot $\mathrm{Cu}\left(\mathrm{mg} \mathrm{kg}^{-1}\right)$ for responses of shoot length and root length in lettuce, along with the $95 \%$ confidence intervals.

\begin{tabular}{lccc}
\hline & \multicolumn{3}{c}{ Effective concentration of shoot $\mathrm{Cu}$ in lettuce $\left(\mathrm{mg} \mathrm{kg}^{-1}\right)$} \\
\cline { 2 - 4 } & $\mathrm{EC}_{10}$ & $\mathrm{EC}_{25}$ & $\mathrm{EC}_{50}$ \\
\hline Shoot length & 11 & 16 & 21 \\
& $(7-16)$ & $(13-20)$ & $(17-26)$ \\
Root length & 12 & 17 & 21 \\
& $(10-15)$ & $(15-19)$ & $(20-23)$ \\
\hline
\end{tabular}

The derived $\mathrm{EC}_{10}$ values are higher than the shoot $\mathrm{Cu}$ concentration of $10 \mathrm{mg} \mathrm{kg}^{-1}$, which is considered as normal for lettuce (Davis and Beckett, 1978; Lamb et al., 2012). Similarly, Lamb et al. (2012) reported an $\mathrm{EC}_{50}$ of $19 \mathrm{mg} \mathrm{kg}^{-1}$ for shoot $\mathrm{Cu}$ concentration in lettuce, which is equal to the $\mathrm{EC}_{50}$ found in our study (Table 1). This shoot $\mathrm{Cu}$ threshold was exceeded in the soils 14 and 23, in which the total soil $\mathrm{Cu}$ concentrations were $898 \mathrm{mg} \mathrm{kg}^{-1}$ and $549 \mathrm{mg} \mathrm{kg}^{-1}$, respectively. The soil number 13 was a soil with high total soil $\mathrm{Cu}$ but where high total Olsen-P masked the $\mathrm{Cu}$ effects and which resulted in rather good growth and lower shoot $\mathrm{Cu}$ (See Online Supplementary Tables 3 and 4). These findings suggest that lettuce shoot $\mathrm{Cu}$ concentrations can be useful as indicators of $\mathrm{Cu}$ toxicity, even in soils with a wide range of nutrient concentrations.

\section{Conclusions}

Growth of lettuce was related to soil total $\mathrm{Cu}$ concentration and Olsen-P and was not affected by soluble $\mathrm{Cu}$ (extractable by $0.1 \mathrm{M} \mathrm{KNO}_{3}$ ) or $\mathrm{Cu}^{2+}$ free ion activity of the soil solution. Thus, lettuce has a limited applicability for metal toxicity assessment in metalcontaminated soils, due to sensitivity of its response to $\mathrm{P}$ deficiency. However, it was possible to determine toxic thresholds for shoot concentrations of $\mathrm{Cu}$ in lettuce for responses of shoot and root length, suggesting that shoot concentrations of $\mathrm{Cu}$ in lettuce can be useful as indicators of $\mathrm{Cu}$ toxicity even in soils with a wide range of nutrient concentrations.

\section{Acknowledgement}

This study was funded by the FONDECYT project 1130041.

\section{References}

Adriano, D.C. 2001. Trace elements in terrestrial environments: Biogeochemistry, bioavailability, and risk of metals. Springer-Verlag, New York, NY.

Davis, R.D., Beckett, P.H.T., 1978. Upper Critical Levels of Toxic Elements in Plants: 2 Critical Levels of Copper in Young Barley, Wheat, Rape, Lettuce and Ryegrass, and of Nickel and Zinc in Young Barley and Ryegrass. New Phytologist. 80, 23-32. 
De Gregori, I. 2003. Monitoring of copper, arsenic and antimony levels in agricultural soils impacted and non-impacted by mining activities, from three regions in Chile. Journal of Environmental Monitoring. 5, 287-295.

Ginocchio, R. 2000. Effects of a copper smelter on a grassland community in the Puchuncavi Valley, Chile. Chemosphere. 41, 15-23.

Ginocchio, R., et al. 2004. Micro-spatial variation of soil metal pollution and plant recruitment near a copper smelter in Central Chile. Environmental Pollution. 127, 343-352.

González, S., et al., 1984. Contaminación con metales pesados del área vecina a una fundición de cobre. Catemu, V Región. Agricultura Técnica (Chile). 44, 63-68.

Hamels, F., et al., 2014. Phytotoxicity of trace metals in spiked and field-contaminated soils: Linking soil-extractable metals with toxicity Environmental Toxicology and Chemistry. 33, 2479-2487.

ISO 11269-2, 2005. Soil quality - Determination of the effects of pollutants on soil flora - Part 2: Effects of chemicals on the emergence and growth of higher plants. International Organization for Standardization, Genève, Switzerland.

ISO 11269-2, 2012. Soil quality - Determination of the effects of pollutants on soil flora - Part 2: Effects of chemicals on the emergence and growth of higher plants. International Organization for Standardization, Genève, Switzerland.

Lamb, D.T., et al., 2012. Copper phytotoxicity in native and agronomical plant species. Ecotoxicology and Environmental Safety. 85, 23-29.

McBride, M.B., 1994. Environmental Chemistry of Soils. Oxford University Press, New York, NY.
McBride, M.B., et al., 2009. A comparison of tests for extractable copper and zinc in metal-spiked and field-contaminated soil. Soil Science. 174, 439444.

OECD 208, 2006. Guidelines for the testing of chemicals. Terrestrial Plant Test: Seedling Emergence and Seedling Growth Test. Organisation for Economic Co-operation and Development, Paris, France.

Reuther, W. 1957. Copper and soil fertility. Soil—US Dep. Agriculture Yearbook. 128-135.

Rhoads, F.M., et al., 1992. Copper Toxicity and Phosphorus Concentration in Florida-502 Oats. Soil and Crop Science Society of Florida Proceedings. 51, 18-20.

Rooney, C.P., et al., 2006. Soil factors controlling the expression of copper toxicity to plants in a wide range of European soils. Environmental Toxicology and Chemistry. 25, 726-732.

Smolders, E., et al., 2009. Toxicity of trace metals in soil as affected by soil type and aging after contamination: Using calibrated bioavailability models to set ecological soil standards. Environmental Toxicology \& Chemistry. 28, 1633-1642.

US EPA, 2013. Toxicity Relationship Analysis Program (TRAP) version 1.22 United States Environmental Protection Agency, Mid-Continent Ecology Division, http://www.epa.gov/med/ Prods_Pubs/trap.htm.

Verdejo, J., et al., 2015. Thresholds of copper phytotoxicity in field-collected agricultural soils exposed to copper mining activities in Chile. Ecotoxicology and Environmental Safety. 122, 171-177. 